\title{
Ecohydraulics: An Introduction
}

\author{
Ian Maddock ${ }^{1}$, Atle Harby ${ }^{2}$, Paul Kemp ${ }^{3}$ and Paul Wood ${ }^{4}$ \\ ${ }^{1}$ Institute of Science and the Environment, University of Worcester, Henwick Grove, Worcester, WR2 6AJ, UK \\ ${ }^{2}$ SINTEF Energy Research, P.O. Box 4761 Sluppen, 7465 Trondheim, Norway \\ ${ }^{3}$ International Centre for Ecohydraulics Research, University of Southampton, Highfield, Southampton, SO17 1BJ, UK \\ ${ }^{4}$ Department of Geography, Loughborough University, Leicestershire, LE11 3TU, UK
}

\subsection{Introduction}

It is well established that aquatic ecosystems (streams, rivers, estuaries, lakes, wetlands and marine environments) are structured by the interaction of physical, biological and chemical processes at multiple spatial and temporal scales (Frothingham et al., 2002; Thoms and Parsons, 2002; Dauwalter et al., 2007). The need for interdisciplinary research and collaborative teams to address research questions that span traditional subject boundaries to address these issues has been increasingly recognised (Dollar et al., 2007) and has resulted in the emergence of new 'sub-disciplines' to tackle these questions (Hannah et al., 2007). Ecohydraulics is one of these emerging fields of research that has drawn together biologists, ecologists, fluvial geomorphologists, sedimentologists, hydrologists, hydraulic and river engineers and water resource managers to address fundamental research questions that will advance science and key management issues to sustain both natural ecosystems and the demands placed on them by contemporary society.

Lotic environments are naturally dynamic, characterised by variable discharge, hydraulic patterns, sediment and nutrient loads and thermal regimes that may change temporally (from seconds to yearly variations) and spatially (from sub-cm within habitat patches to hundreds of $\mathrm{km}^{2}$ at the drainage basin scale). This complexity produces a variety of geomorphological features and habitats that sustain the diverse ecological communities recorded in fresh, saline and marine waters. Aquatic organisms, ranging from micro-algae and macro- phytes to macroinvertebrates, fish, amphibians, reptiles, birds and mammals, have evolved adaptations to persist and thrive in hydraulically dynamic environments (Lytle and Poff, 2004; Townsend, 2006; Folkard and Gascoigne, 2009; Nikora, 2010). However, anthropogenic impacts on aquatic systems have been widespread and probably most marked on riverine systems. A report by the World Commission on Dams (2000) and a recent review by Kingsford (2011) suggested that modification of the river flow regime as a result of regulation by creating barriers, impoundment and overabstraction, the spread of invasive species, overharvesting and the effects of water pollution were the main threats to the world's rivers and wetlands and these effects could be compounded by future climate change.

The impacts of dam construction, river regulation and channelisation have significantly reduced the natural variability of the flow regime and channel morphology. This results in degradation, fragmentation and loss of habitat structure and availability, with subsequent reductions in aquatic biodiversity (Vörösmarty et al., 2010). Recognition of the long history, widespread and varied extent of human impacts on river systems, coupled with an increase in environmental awareness has led to the development of a range of approaches to minimise and mitigate their impacts. These include river restoration and rehabilitation techniques to restore a more natural channel morphology (e.g. Brookes and Shields Jr, 1996; de Waal et al., 1998; Darby and Sear, 2008), methods to define ways to reduce or mitigate the impact of abstractions and river regulation through the definition and application of instream

Ecohydraulics: An Integrated Approach, First Edition. Edited by Ian Maddock, Atle Harby, Paul Kemp and Paul Wood.

(C) 2013 John Wiley \& Sons, Ltd. Published 2013 by John Wiley \& Sons, Ltd. 


\section{Ecohydraulics: An Integrated Approach}

or environmental flows (Dyson et al., 2003; Acreman and Dunbar, 2004; Annear et al., 2004; Acreman et al., 2008), and the design of screens and fish passes to divert aquatic biota from hazardous areas (e.g. abstraction points) and to enable them to migrate past physical barriers, especially, but not solely associated with dams (Kemp, 2012).

Key legislative drivers have been introduced to compel regulatory authorities and agencies to manage and mitigate historic and contemporary anthropogenic impacts and, where appropriate, undertake restoration measures. The EU Water Framework Directive (Council of the European Communities, 2000) requires the achievement of 'good ecological status' in all water bodies across EU member states by 2015 (European Commission, 2012). This, in turn, has required the development of methods and techniques to assess the current status of chemical and biological water quality (Achleitner et al., 2005), hydromorphology and flow regime variability, and identify ways of mitigating impacts and restoring river channels and flow regimes where they are an impediment to the improvement of river health (Acreman and Ferguson, 2010). Similar developments have occurred in North America with the release of the United States Environmental Protection Agency guidelines (US EPA, 2006). In Australia, provision of water for environmental flows has been driven by a combination of national policy agreements including the National Water Initiative in 2004, national and state level legislation and governmentfunded initiatives to buy back water entitlements from water users including the 'Water for the Future' programme (Le Quesne et al., 2010). Important lessons can be learned from South Africa, where implementation of the National Water Act of 1998 is recognised as one of the most ambitious pieces of water legislation to protect domestic human needs and environmental flows on an equal footing ahead of economic uses. However, Pollard and du Toit (2008) suggest that overly complicated environmental flow recommendations have inhibited their implementation. This provides a key message for ecohydraulic studies aimed at providing environmental flow or indeed other types of river management recommendations (e.g., river restoration) worldwide.

\subsection{The emergence of ecohydraulics}

During the 1970s and 1980s it was common for multidisciplinary teams of researchers and consultants to undertake pure and/or applied river science projects and to present results collected as part of the same study inde- pendently to stakeholders and regulatory/management authorities, each from the perspective of their own disciplinary background. More recently, there has been a shift towards greater interdisciplinarity, with teams of scientists, engineers, water resource and river managers and social scientists working together in collaborative teams towards clearly defined common goals (Porter and Rafols, 2009). Developments in river science reflect this overall pattern, with the emergence of ecohydrology at the interface of hydrology and ecology (Dunbar and Acreman, 2001; Hannah et al., 2004; Wood et al., 2007) and hydromorphology, which reflects the interaction of the channel morphology and flow regime (hydrology and hydraulics) in creating 'physical habitat' (Maddock, 1999; Orr et al., 2008; Vaughan et al., 2009).

Like 'ecohydrology', 'ecohydraulics' has also developed at the permeable interface of traditional disciplines, combining the study of the hydraulic properties and processes associated with moving water typical of hydraulic engineering and geomorphology and their influence on aquatic ecology and biology (Vogel, 1996; Nestler et al., 2007). Ecohydraulics has been described as a subdiscipline of ecohydrology (Wood et al., 2007) although it has become increasingly distinct in recent years (Rice et al., 2010). Hydraulic engineers have been engaged with design criteria for fish passage and screening facilities at dams for many years. Recognition of the need to solve river management problems like these by adopting an interdisciplinary approach has been the driver for the development of ecohydraulics. Interdisciplinary research that incorporates the expertise of hydrologists, fluvial geomorphologists, engineers, biologists and ecologists has begun to facilitate the integration of the collective expertise to provide holistic management solutions. Ecohydraulics has played a critical role in the development of methods to assess and define environmental flows (Statzner et al., 1988). Although pre-dating the use of the term 'ecohydraulics', early approaches, such as the Physical Habitat Simulation System (PHABSIM) in the 1980s and 1990s, were widely applied (Gore et al., 2001) but often criticised due to an over-reliance on simple hydraulic models and a lack of ecological relevance because of the way that habitat suitability was defined and calculated (Lancaster and Downes, 2010; Shenton et al., 2012). State-ofthe-art developments associated with ecohydraulics are attempting to address these specific gaps between physical scientists (hydraulic engineers, hydrologists and fluvial geomorphologists) and biological scientists (e.g. aquatic biologists and ecologists) by integrating hydraulic and biological tools to analyse and predict ecological responses 
to hydrological and hydraulic variability and change (Lamouroux et al. in press). These developments intend to support water resource management and the decisionmaking process by providing ecologically relevant and environmentally sustainable solutions to issues associated with hydropower operations, river restoration and the delineation of environmental flows (Acreman and Ferguson, 2010).

The growing worldwide interest in ecohydraulics can be demonstrated by increasing participation in the international symposia on the subject. The first symposium (then titled the 1st International Symposium on Habitat Hydraulics) was organised in 1994 in Trondheim, Norway by the Foundation for Scientific and Industrial Research (SINTEF), the Norwegian University of Science and Technology (NTNU) and the Norwegian Institute of Nature Research (NINA) with about 50 speakers and 70 delegates. Subsequent symposia in Quebec City (Canada, 1996), Salt Lake City (USA, 1999), Cape Town (South Africa, 2002), Madrid (Spain, 2004), Christchurch (New Zealand, 2007), Concepción (Chile, 2009), Seoul (South Korea, 2010) and most recently in Vienna (Austria, 2012) have taken the scientific community across the globe, typically leading to more than 200 speakers and approximately 300 delegates at each meeting.

A recent bibliographic survey by Rice et al. (2010) indicated that between 1997 and the end of 2009 a total of 146 publications had used the term 'ecohydraulic' or a close variant (eco hydraulic, ecohydraulics or eco-hydraulics) in the title, abstract or keywords (ISI Web of Knowledge, http://wok.mimas.ac.uk/). This meta-analysis indicated greater use of the term 'ecohydraulics' amongst water resources and engineering journals (48\%) and geoscience journals (31\%) compared to a more limited use in $(21 \%)$ biological or ecological journals. By the end of 2011 this figure had risen to 211 publications, with 65 papers being published between 2010 and the end of 2011 (Figure 1.1). This suggests a significant increase in the use of the terms more recently, and strongly mirrors the rapid rise in the use of the term 'ecohydrology', which has been used in the title, abstract or as a keyword 635 times since 1997 (186 between 2010 and 2011). However, bibliographic analysis of this nature only identifies those publications that have specifically used one of the terms and there is an extensive unquantified literature centred on ecohydraulics and ecohydrology that has not specifically used these terms.

Porter and Rafols (2009) suggested that interdisciplinary developments in science have been greatest between closely allied disciplines and less well developed and slower for fields with a greater distance between them.

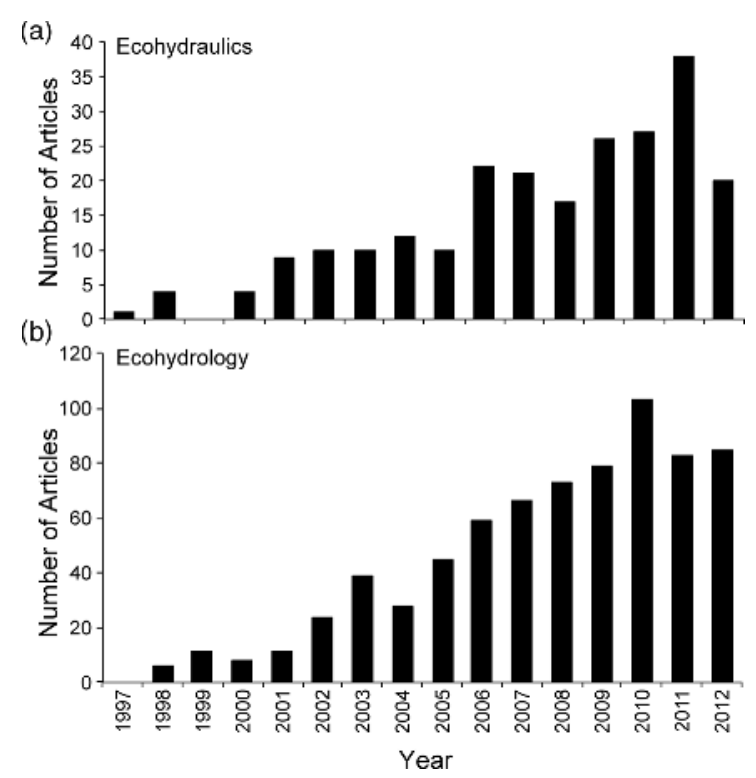

Figure 1.1 Number of peer-reviewed articles using the terms (a) ecohydraulic(s), eco-hydraulic(s) or eco hydraulic(s) and (b) ecohydrology, eco-hydrology or eco hydrology 1997-2012 as listed on Thomson Reuters ISI Web of Knowledge

(http://wok.mimas.ac.uk/). Note: WoK data for 2012 compiled on $22 / 11 / 2012$.

This appears to be the case when comparing developments in ecohydrology and ecohydraulics. Ecohydrology has increasingly been embraced by an interdisciplinary audience and even witnessed the launch of a dedicated journal, Ecohydrology, in 2008 (Smettem, 2008), drawing contributions from across physical, biological and social sciences as well as engineering and water resources management. In contrast, publications explicitly referring to 'ecohydraulics' predominately appeared in water resources, geosciences and engineering journals and the affiliation of the primary authors remains firmly within engineering and geosciences departments and research institutes. However, the greatest number of papers has appeared in the interdisciplinary journal River Research and Applications (17 papers since 2003). This figure includes five out of ten papers within a special issue devoted to ecohydraulics in 2010 (Rice et al., 2010) and two out of nine papers within a special issue devoted to 'Fish passage: an ecohydraulics approach' in 2012 (Kemp, 2012), and clearly demonstrates that many authors do not routinely use the term 'ecohydraulics'. Biologists have been investigating organism responses to their abiotic environments, including the role of fluid dynamics on aquatic communities, for decades and well before the term 'ecohydraulics' was coined. For 


\section{Ecohydraulics: An Integrated Approach}

example, from an environmental flow perspective, biological scientists have been involved with determining the relationship between fish (and other biota) and hydraulics since at least the 1970s (e.g. Bovee and Cochnauer, 1978). What this bibliographic analysis highlights is that geoscientists and engineers have more readily adopted the terms than colleagues in biology and ecology.

The dominance of physical scientists and engineers within some studies, many of them using modelling approaches, has been highlighted as a potential weakness of some research. It is argued they rely on faulty assumptions and lack any ecological or biological reality due to inadequate consideration of biological interactions between organisms (inter- or intra-specific), or natural population dynamics (Lancaster and Downes, 2010; Shenton et al., 2012). However, these criticisms have been contested and there is growing evidence that interdisciplinarity is being embraced more widely (Lamouroux et al., 2010; Lamouroux et al., Lamouroux et al., in press). This issue is discussed further in the concluding chapter of this volume.

\subsection{Scope and organisation of this book}

The aim of this research-level edited volume is to provide the first major text to focus on ecohydraulics. It is comprised of chapters reflecting the range and scope of research being undertaken in this arena (spanning engineering, geosciences, water resources, biology, ecology and interdisciplinary collaborations). Individual chapter authors have provided overviews of cutting-edge research and reviews of the current state of the art in ecohydraulics. In particular, authors have been encouraged to demonstrate how their work has been informed by and is influencing the on-going development of ecohydraulics research. The contributions use case study examples from across the globe, highlighting key methodological developments and demonstrating the real-world application of ecohydraulic theory and practice in relation to a variety of organisms ranging from riparian vegetation and instream algae, macrophytes, macroinvertebrates and fish to birds and amphibians. The chapters reflect a spectrum of research being undertaken within this rapidly developing field and examine the interactions between hydraulics, hydrology, fluvial geomorphology and aquatic ecology on a range of spatial (individual organism in a habitat patch to catchment) and temporal scales.

The book is structured into four parts: Part One considers the range and type of methods and approaches used in ecohydraulics research, with a particular focus on aquatic habitat modelling; Part Two considers a range of species-habitat relationships in riverine and riparian habitats; Part Three consists of detailed ecohydraulics case studies that have a clear management application, mostly, but not exclusively, relating to environmental flow determination, fish passage design, river channel and habitat restoration and ecosystem assessment. The final chapter (Part Four) aims to draw together the work contained in the book to outline key research themes and challenges in ecohydraulics and discuss future goals and directions. A number of chapters involve methods, species-habitat relationships and case studies and therefore could have been located in more than one part of the book. The final decision regarding which part to place them in was in some cases clear-cut and in others fairly arbitrary.

We realise that the coverage provided in this volume is not complete and are conscious that the chapters are almost exclusively centred on freshwater, riverine ecosystems. Indeed there has been a considerable volume of research centred on marine (e.g. Volkenborn et al., 2010), estuarine (e.g. Yang et al., 2012) and lentic (lake) ecosystems (e.g. Righetti and Lucarelli, 2010), where equally challenging and exciting ecohydraulic research questions are being addressed. Their exclusion is driven by a desire to keep this book within a manageable size and scope rather than a view that these other parts of the natural environment are somehow less important than riverine ecosystems.

Research currently being undertaken in the arena of ecohydraulics is developing rapidly and is becoming increasingly interdisciplinary, drawing on a range of academic and practitioner traditions and addressing realworld problems. As this interdisciplinary science matures there is a growing demand from river managers and end users to be involved not just at the inception and conclusion, but throughout the studies to enhance the possibility that any management recommendations can be implemented successfully. The occurrence of this would signal a move from interdisciplinarity (between traditional disciplines) to 'transdisciplinarity' (that also engages with managers and end users during the research). The editors hope that the realisation of this development will be one mark of this book's success.

\section{References}

Achleitner, S., de Toffol, S., Engelhard, C. and Rauch, W. (2005)

The European Water Framework Directive: water quality 
classification and implications to engineering planning. Environmental Management, 35: 517-525.

Acreman, M. and Dunbar, M.J. (2004) Defining environmental flow requirements - a review. Hydrology and Earth System Sciences, 8: 861-876.

Acreman, M., Dunbar, M., Hannaford, J., Mountfield, O., Wood, P., Holmes, N., Cowx, I., Noble, R., King, J., Black, A., Extence, C., Aldrick, J., Kink, J., Black, A. and Crookall, D. (2008) Developing environmental standards for abstractions from UK rivers to implement the EU Water Framework Directive. Hydrological Sciences Journal, 53: 1105-1120.

Acreman, M. and Ferguson, A.J.D. (2010) Environmental flows and the European Water Framework Directive. Freshwater Biology, 55: 32-48.

Annear, T., Chisholm, I., Beecher, H., Locke, A. et al. (2004) Instream Flows for Riverine Resource Stewardship, (revised edition). Instream Flow Council, Cheyenne, WY.

Bovee, K.D. and Cochnauer, T. (1978) Development and evaluation of weighted criteria, probability-of-use curves for instream flow assessment: fisheries. Instream Flow Information Paper No. 3. Cooperative Instream Flow Service Group, Western Energy and Land Use Team, Office of Biological Services, Fish and Wildlife Service, U.S. Dept. of the Interior.

Brookes, A. and Shields Jr., F.D. (eds) (1996) River Channel Restoration: Guiding Principles for Sustainable Projects, John Wiley \& Sons, Ltd, Chichester, UK.

Council of the European Communities (2000) Directive 2000/60/EC of the European Parliament and of the Council of 23 October 2000 establishing a framework for Community action in the field of water policy. Official Journal of the European Communities, L327: 1-73.

Darby, S. and Sear, D. (eds) (2008) River Restoration: Managing the Uncertainty in Restoring Physical Habitat, John Wiley \& Sons, Ltd, Chichester, UK.

Dauwalter, D.C., Splinter, D.K., Fisher, W.L. and Marston, R.A. (2007) Geomorphology and stream habitat relationships with smallmouth bass (Micropterus dolomieu) abundance at multiple spatial scales in eastern Oklahoma. Canadian Journal of Fisheries and Aquatic Sciences, 64: 1116-1129.

de Waal, L.C., Large, A.R.G. and Wade, P.M. (eds) (1998) Rehabilitation of Rivers: Principles and Implementation, John Wiley \& Sons, Ltd, Chichester, UK.

Dollar, E.S.J., James, C.S., Rogers, K.H. and Thoms, M.C. (2007) A framework for interdisciplinary understanding of rivers as ecosystems. Geomorphology, 89: 147-162.

Dunbar, M.J. and Acreman, M. (2001) Applied hydro-ecological science for the twenty-first century. In Acreman, M. (ed.) Hydro-Ecology: Linking Hydrology and Aquatic Ecology. IAHS Publication no. 288. pp. 1-17.

Dyson, M., Bergkamp, G. and Scanlon, J. (eds) (2003) Flow: The Essentials of Environmental Flows. IUCN, Gland, Switzerland and Cambridge, UK.

European Commission (2012) The EU Water Framework Directive: integrated river basin management for Europe. Available at: http://ec.europa.eu/environment/water/water-framework/ index_en.html [Date accessed: 20/7/12].

Folkard, A.M. and Gascoigne, J.C. (2009) Hydrodynamics of discontinuous mussel beds: Laboratory flume simulations. Journal of Sea Research, 62: 250-257.

Frothingham, K.M., Rhoads, B.L. and Herricks, E.E. (2002) A multiple conceptual framework for integrated ecogeomorphological research to support stream naturalisation in the agricultural Midwest. Environmental Management, 29: 16-33.

Gore, J.A., Layzer, J.B. and Mead, J. (2001) Macroinvertebrate instream flow studies after 20 years: A role in stream management and restoration. Regulated Rivers: Research and Management, 17: 527-542.

Hannah, D.M., Wood, P.J. and Sadler, J.P. (2004) Ecohydrology and hydroecology: a new paradigm. Hydrological Processes, 18: 3439-3445.

Hannah, D.M., Sadler, J.P. and Wood, P.J. (2007) Hydroecology and ecohydrology: a potential route forward? Hydrological Processes, 21: 3385-3390.

Kemp, P. (2012) Bridging the gap between fish behaviour, performance and hydrodynamics: an ecohydraulics approach to fish passage research. River Research and Applications, 28: 403-406.

Kingsford, R.T. (2011) Conservation management of rivers and wetlands under climate change-a synthesis. Marine and Freshwater Research, 62: 217-222.

Lamouroux, N., Merigoux, S., Capra, H., Doledec, S., Jowette, I.G. and Statzner, B. (2010) The generality of abundanceenvironment relationships in micro-habitats: a comment on Lancaster and Downes (2009). River Research and Applications, 26: 915-920.

Lamouroux, N., Merigoux, S., Doledec, S. and Snelder, T.H. (in press) Transferability of hydraulic preference models for aquatic macroinvertebrates. River Research and Applications, DOI: 10.1002/rra.2578.

Lancaster, J. and Downes, B.J. (2010) Linking the hydraulic world of individual organisms to ecological processes: putting ecology into ecohydraulics. River Research and Applications, 26: 385-403.

Le Quesne, T., Kendy, E. and Weston, D. (2010) The Implementation Challenge: taking stock of government policies to protect and restore environmental flows. The Nature Conservancy, World Wide fund for Nature Report, 2010. Available at: http://19assets.dev.wwf.org.uk/downloads/global_flows.pdf [Date accessed: 19/10/12].

Lytle, D.A. and Poff, N.L. (2004) Adaptation to natural flow regimes. Trends in Ecology and Evolution, 19: 94-100.

Maddock, I. (1999) The importance of physical habitat assessment for evaluating river health. Freshwater Biology, 41: 373391.

Nestler, J.M., Goodwin, R.A., Smith, D.L. and Anderson, J.J. (2007) A mathematical and conceptual framework for ecohydraulics. In Wood, P.J., Hannah, D.M. and Sadler, J.P. (eds) Hydroecology and Ecohydrology: Past, Present and Future, John Wiley \& Sons, Ltd, Chichester, UK, pp. 205-224. 


\section{Ecohydraulics: An Integrated Approach}

Nikora, V. (2010) Hydrodynamics of aquatic ecosystems: An interface between ecology, biomechanics and environmental fluid mechanics. River Research and Applications, 26: 367-384.

Orr, H.G., Large, A.R.G., Newson, M.D. and Walsh, C.L. (2008) A predictive typology for characterising hydromorphology. Geomorphology, 100: 32-40.

Pollard, S. and du Toit, D. (2008) Integrated water resource management in complex systems: how the catchment management strategies seek to achieve sustainability and equity in water resources in South Africa. Water SA 34 (IWRM Special Edition): 671-679. Available at: http://www.scielo.org.za/pdf/ wsa/v34n6/a03v34n6.pdf [Date accessed: 19/10/12].

Porter, A.L. and Rafols, I. (2009) Is science becoming more interdisciplinary? Measuring and mapping six research fields over time. Scientometrics, 81: 719-745.

Rice, S.P., Little, S., Wood, P.J., Moir, H.J. and Vericat, D. (2010) The relative contributions of ecology and hydraulics to ecohydraulics. River Research and Applications, 26: 1-4.

Righetti, M. and Lucarelli, C. (2010) Resuspension phenomena of benthic sediments: the role of cohesion and biological adhesion. River Research and Applications, 26: 404-413.

Shenton, W., Bond, N.R., Yen, J.D.L. and MacNally, R. (2012) Putting the "Ecology" into environmental flows: ecological dynamics and demographic modelling. Environmental Management, 50: 1-10.

Smettem, K.R.J. (2008) Editorial: Welcome address for the new 'Ecohydrology' Journal. Ecohydrology, 1: 1-2.

Statzner, B., Gore, J.A. and Resh, J.V. (1988) Hydraulic stream ecology-observed patterns and potential applications. Journal of the North American Benthological Society, 7: 307-360.

Thoms, M.C. and Parsons, M. (2002) Eco-geomorphology: an interdisciplinary approach to river science. In Dyer, F.J., Thoms, M.C. and Olley, J.M. (eds) The Structure, Function and Management Implications of Fluvial Sedimentary Systems (Proceedings of an international symposium held at Alice Springs, Australia, September 2002) International Association of Hydrological Sciences, 276: 113-119.
Townsend, S.A. (2006) Hydraulic phases, persistent stratification, and phytoplankton in a tropical floodplain lake (Mary River, northern Australia). Hydrobiologia, 556: $163-179$.

USEPA (2006) Guidance for 2006 Assessment, Listing and Reporting Requirements Pursuant to Sections 303(d), 305(b) and 314 of the Clean Water Act. http://water.epa.gov/lawsregs/ lawsguidance/cwa/tmdl/upload/2006irg-report.pdf

Vaughan, I.P., Diamond, M., Gurnell, A.M., Hall, K.A., Jenkins, A., Milner, N.J., Naylor, L.A., Sear, D.A., Woodward, G. and Ormerod, S.J. (2009) Integrating ecology with hydromorphology: a priority for river science and management. Aquatic Conservation: Marine and Freshwater Ecosystems, 19: $113-125$.

Vogel, S. (1996) Life in moving fluids: the physical biology of flow. Princeton University Press, Princeton.

Volkenborn, N., Polerecky, L., Wethey, D.S. and Woodin. S.A. (2010) Oscillatory porewater bioadvection in marine sediments induced by hydraulic activities of Arenicola marina. Limnology and Oceanography, 55: 1231-1247.

Vörösmarty, C.J., McIntyre, P.B., Gessner, M.O., Dudgeon, D., Prusevich, A., Green, P., Glidden, S., Bunn, S.E., Sullivan, C.A., Reidy Liermann, C. and Davies, P.M. (2010) Global threats to human water security and river biodiversity. Nature, 467: 555561.

Wood, P.J., Hannah, D.M. and Sadler, J.P. (eds) (2007) Hydroecology and Ecohydrology: An Introduction. In Wood, P.J., Hannah, D.M. and Sadler, J.P. (eds) Hydroecology and Ecohydrology: Past, Present and Future, John Wiley \& Sons, Ltd, Chichester, UK, pp. 1-6.

World Commission on Dams (2000) Dams and Development: a new framework for decision-making. The report of the World Commission on Dams. Earthscan.

Yang, Z., Wang, T., Khangaonkar, T. and Breithaupt, S. (2012) Integrated modelling of flood flows and tidal hydrodynamics over a coastal floodplain. Environmental Fluid Mechanics, 12: 63-80. 